\title{
Insulin Edema in Type 1 Diabetes Mellitus: Report of a Case and Brief Review of the Literature
}

\author{
Ayse Derya Bulus, ${ }^{1,}$ Nesibe Andiran, ${ }^{1}$ and Ali Osman Köksal ${ }^{2}$ \\ ${ }^{1}$ Department of Endocrinology, Kecioren Training and Research Hospital, Ankara, Turkey \\ ${ }^{2}$ Kecioren Training and Research Hospital, Ankara, Turkey \\ "Corresponding author: Ayse Derya Bulus, Department of Endocrinology, Kecioren Training and Research Hospital, Ankara, Turkey. Tel: +90-5326335052, Fax: +90-3569002, \\ E-mail: drderyabulus@hotmail.com
}

Received 2015 December 18; Accepted 2016 January 09.

Keywords: Type 1 Diabetes, Insulin, Hyperglycemia

\section{Dear editor,}

Despite the essential role of insulin therapy in the management of patients with insulin deficiency, insulin itself may lead to adverse effects such as hypoglycemia and weight gain $(1,2)$. Additionally, crucial fluid retention can also occur rarely, resulting in an edematous condition. Peripheral or generalized edema is an extremely rare complication of insulin therapy, which mostly occurs after the initiation of intensive insulin therapy $(3,4)$.

Here we report a 12-year-old boy with newly diagnosed type 1 diabetes, presented with edema of the lower extremities about one week after the initiation of insulin therapy with a brief review of the literature.

A 12-year-old boy was admitted to the hospital with an acute presentation of DKA. In his history, polyuria and polydipsia were present for two months with a recent weight loss of $4 \mathrm{~kg}$. No family history of diabetes was reported. On physical examination, his height was $152 \mathrm{~cm}$ (-0.31 SD) and weight was $30 \mathrm{~kg}(-1.75 \mathrm{SD})$, body mass index was 13 $\mathrm{kg} / \mathrm{m}^{2}(\mathrm{P}<3)$, heart rate was 110 minutes, blood pressure $100 / 70 \mathrm{mmHg}$. He had somnolance, mild dehydration, and "Kussmaul" breathing. Findings of other systems on examination were within normal range. Laboratory findings; blood glucose level was $800 \mathrm{mg} / \mathrm{dL}$, ketonuria with acidosis was present with venous blood $\mathrm{pH}$ of 7.0. HbA1c level was $16 \%$ (normal range $4 \%-6 \%$ ). He was initially treated with intravenous insulin infusion and isotonic saline (in 5\% dextrose). After completing intensive DKA treatment, subcutaneous regular insulin treatment was started for determination of daily insulin requirement. And then it was switched to intensive insulin regimen as fast acting insulin (insulin lispro) before meals and insulin glargine at bed time with a total daily insulin requirement of $1.2 \mathrm{U} / \mathrm{kg} /$ day.

On the 4th day of this treatment protocol, edema was developed, which initially involved the patient's ankles and rapidly progressed to his legs and face,. It was a non- tender, pitting edema without any skin discoloration and it resulted in weight gain of about $10 \mathrm{~kg}$ within 5 days.

Serum albumin level decreased from 3.6 to $2.9 \mathrm{~g} / \mathrm{dL}$ (normal range: $3.5-5.5 \mathrm{~g} / \mathrm{dL}$ ), with mild proteinuria. His total protein was $5.06 \mathrm{~g} / \mathrm{dL}$ (normal range: 6 - $8 \mathrm{~g} / \mathrm{dL}$ ).

Now our patient is 13 years old. He is managed on multiple subcutaneous insulin injections per day, his initial insulin requirement was 0.8 units $/ \mathrm{kg} /$ day with excellent glycemic control ( $\mathrm{HbA1C}=7.4 \%$ ). There is no history of recurrence of insulin edema in our patient.

Edema has been recognized as an uncommon complication of insulin treatment which mostly occurs during initiation or intensification of insulin therapy. Edema associated with insulin therapy may occur in local areas such as pretibial, sacral or periorbital regions or may be generalized (4). The incidence of insulin-induced edema in children with type 1 diabetes is unknown. Up to now, to our best knowledge, there are 15 Type 1 diabetic children or adolecent patients with insulin edema reported in the literature (Table 1$)$.

All previously reported pediatric cases were patients with newly diagnosed T1DM, with a mean age of 13.5 (9 19) years, in similar age to our patients ( 9 of 15 patients). Only 4 of them were male, with female/male ratio of 2.75 indicating a clear female predominance. However insulininduced edema in adults was reported to occur equally in males and females. Twelve of 15 patients had peripheral edema and one of them had peripheral and generalized edema. Ten of 15 patients needed no specific medical treatment, insulin edema resolved completely. Only 5 patients had required medical treatment for insulin edema $(3,4)$ (Table 1).

For treatment of insulin induced edema, fluid and salt restriction should be implemented and may be all that is necessary. Diuretic therapy might be indicated in severe and/or decompensated cases. An aldosterone antagonist 
Table 1. Type 1 Diabetic Patients Reported With Insulin Edema in the Literature

\begin{tabular}{|c|c|c|c|c|c|c|c|}
\hline Patient & Gender & Age & BMI, $\mathrm{kg} / \mathrm{m}^{2}$ & Type I DM, y & Insulin Dose, $\mathrm{U} / \mathrm{kg} / \mathrm{day}$ & Edema & Treatment \\
\hline 1 & Male & 12 & $15(<3 p)$ & 2 & 1.5 & Peripheral & Spontaneus \\
\hline 2 & Male & 16 & & 15 & NA & NA & Spontaneus \\
\hline 3 & Female & 14 & NA & Newly diagnoed & 1.5 & Peripheral & Spontaneus \\
\hline 4 & Female & 16 & NA & 10 & 1.3 & Peripheral & Spontaneus \\
\hline 5 & Female & 15 & NA & 7 & NA & Peripheral & Spontaneus \\
\hline 6 & Female & 11 & NA & 7 & NA & Peripheral & Spontaneus \\
\hline 7 & Male & 10 & NA & 1 & NA & Peripheral & Diuretic \\
\hline 8 & Female & 13 & $<3 p$ & Newly diagnoed & 2 & Generalised & Diuretic \\
\hline 9 & Female & 14 & NA & Newly diagnoed & 1.5 & Generalised & Diuretic \\
\hline 10 & Female & 12 & 15 & Newly diagnoed & 1.5 & Peripheral & Diuretic \\
\hline 11 & Female & 14 & NA & 1 & 1.5 & Peripheral & Spontaneus \\
\hline 12 & Female & 19 & 15.5 & Newly diagnoed & 2 & Generalised, peripheral & Spontaneus \\
\hline 13 & Female & 14 & $15.6(<3 p)$ & Newly diagnoed & NA & Peripheral & Spontaneus \\
\hline 14 & Female & 11 & $13.8(<3 p)$ & Newly diagnoed & NA & Peripheral & Spontaneus \\
\hline 15 & Male & 9 & 16.7 & Newly diagnoed & 0.91 & Peripheral & Spontaneus \\
\hline 16 & Male & 12 & $13(<3 p)$ & Newly diagnoed & 1.2 & Peripheral & Spontaneus \\
\hline
\end{tabular}

Abbreviation: NA, not available.

such as spirinolactone might be preferred from a pathophysiological point of view with regard to the presence of inappropriate hyperaldosteronism, although therapy with other diuretics appears also similarly effective (5). In most of the reported children in the literature, edema resolved spontaneosly within 7 - 20 days just with fluid and salt restriction, without necessity of diuretics.

In conclusion, we should be aware of the possibility of insulin-induced edema in patients with newly diagnosed T1DM especially in female adolescents with malnutrition and taking high dose daily insulin therapy. Fluid-salt restriction and a careful follow-up should be initiated immediately for prevention of complications.

\section{References}

1. Alemzadeh R, Wyatt D. In: Nelson Textbook of Pediatrics. Behrman RE,
Kliegman RM, Jenson HB, editors. Philadelphia: Saunders; 2004. pp. 1947-72.Diabetes mellitus.

2. Lee P, Kinsella J, Borkman M, Carter J. Bilateral pleural effusions, ascites, and facial and peripheral oedema in a 19-year-old woman 2 weeks following commencement of insulin lispro and detemir-an unusual presentation of insulin oedema. Diabet Med. 2007;24(11):1282-5. doi: 10.1111/j.1464-5491.2007.02241.x. [PubMed: 17956453].

3. Hopkins DF, Cotton SJ, Williams G. Effective treatment of insulin induced edema using ephedrine. Diabetes Care. 1993;16(7):1026-8. [PubMed: 8359096].

4. Bas VN, Cetinkaya S, Agladioglu SY, Kendirici HN, Bilgili H, Yildirim $\mathrm{N}$, et al. Insulin oedema in newly diagnosed type 1 diabetes mellitus. J Clin Res Pediatr Endocrinol. 2010;2(1):46-8. doi: 10.4274/jcrpe.v2i1.46. [PubMed: 21274337]

5. Dornan TL, Jenkins S, Cotton RE, Tattersall RB, Burden RP. The nephrotic syndrome at presentation of insulin-dependent diabetes mellitus; cause or coincidence?. Diabet Med. 1988;5(4):387-90. [PubMed: 2968891]. 